Zeszyty Naukowe Szkoły Głównej Gospodarstwa Wiejskiego w Warszawie

Problemy Rolnictwa Światowego tom 18 (XXXIII), zeszyt 4, 2018: 112-121

DOI: 10.22630/PRS.2018.18.4.102

Jacek Bednarz $^{1}$, Maria Zuba-Ciszewska ${ }^{2}$

Katolicki Uniwersytet Lubelski Jana Pawła II

\title{
Produkcja mleka ekologicznego w Polsce. Koncentracja czy rozproszenie?
}

\section{Organic Milk Production in Poland. Concentration or Dispersion?}

\begin{abstract}
Synopsis. W produkcji ekologicznego mleka w Polsce specjalizują się regiony o niewielkim udziale w produkcji tego surowca ogółem w kraju. Pomiar koncentracji stanowi jedno z kluczowych zagadnień w badaniach nad ekonomicznymi strukturami zjawisk rynkowych. Celem pracy było zbadanie stopnia koncentracji rynku mleka ekologicznego na tle rynku mleka ogółem, a także próba odpowiedzi na pytanie o możliwość wskazania regionów specjalizujących się w produkcji mleka ekologicznego. Badanie przeprowadzono przy pomocy klasycznego indeksu Herfindahla-Hirschmana oraz zmodyfikowanej wersji formuły metody unitaryzacji zerowanej. Uzyskane wyniki wskazują na umiarkowany stopień koncentracji rynku mleka ekologicznego. Jednocześnie, przy wykorzystaniu metody z zakresu porządkowania liniowego, możliwa jest jednoznaczna identyfikacja regionów, w których produkcja mleka ekologicznego ma większe znaczenie ekonomiczne.
\end{abstract}

Slowa kluczowe: produkcja, mleko ekologiczne, regiony, koncentracja, Indeks HerfindahlaHirschmana, metoda unitaryzacji zerowanej

\begin{abstract}
Regions specialized in the organic milk production in Poland represent a small share in the total production of this raw material within the country. Measurement of concentration is one of the key issues in research on the economic structures of market phenomena. The aim of the work was to examine the degree of concentration of the organic milk market in the context of the total milk market, as well as an attempt to answer the question about the possibility of indicating regions specializing in the production of organic milk. The study was carried out using the classical Herfindahl-Hirschman index. A modified version of the formula of the zero unitarization method was also used. The obtained results indicate a moderate degree of concentration of the organic milk market. At the same time, using the modified zero unitarization method, it is possible to clearly identify regions in which the production of organic milk has more economic significance.
\end{abstract}

Key words: production, organic milk, regions, concentration, Herfindahl-Hirschman Index, zero unitarization method

JEL Classification: C49, E23, L11, Q13

\section{Wstęp}

Światowy rynek żywności ekologicznej dynamicznie się rozwija, o czym świadczy ponad pięciokrotny wzrost wartości sprzedaży w okresie 2000-2016 (do 89,7 mld dolarów).

\footnotetext{
${ }^{1}$ dr, Instytut Ekonomii i Zarządzania KUL Jana Pawła II, Al. Racławickie 14, 20-950 Lublin, e-mail: bednarz@kul.lublin.pl; https://orcid.org/0000-0002-9978-037

${ }^{2}$ dr, Instytut Ekonomii i Zarządzania KUL Jana Pawła II, Al. Racławickie 14, 20-950 Lublin, e-mail: maria.zuba@kul.pl; https://orcid.org/0000-0002-5543-1620
} 
Jednym z wyzwań tego rynku jest nadal zbyt duża koncentracja popytu. Ponad $90 \%$ sprzedaży przypada na Europę i Amerykę Północną (z czego 51\% na Amerykę Północna), choć jeszcze w 2008 roku było to $97 \%$ (w tym na Europę 51\%). Koncentracja po stronie podaży również jest widoczna. O ile bowiem w 2008 roku na Oceanię i Europę przypadało ponad 58\% powierzchni ekologicznych użytków rolnych (z czego na Oceanię 34,6\%) to w 2016 roku już ponad 70\% (na Oceanię 47,2\%). Natomiast największy udział producentów ekologicznych na świecie tj. z Azji i Afryki nieznacznie spadł w analogicznym okresie (z 67,8\% do 63,6\%) (Willer, Lernoud, 2018; Weidmann i in., 2010). W 2016 roku ponad 39\% wartości sprzedaży produktów ekologicznych przypadało na Europe, w tym prawie $30 \%$ na 7 krajów o najbardziej chłonnym rynku (Niemcy, Francja, Włochy, Wlk. Brytania, Szwajcaria, Szwecja, Hiszpania). W niektórych z tych krajów udział ekologicznych produktów w danym segmencie jest już znaczący jak np. w przypadku produktów mlecznych (Austria 10,4\%, Niemcy 8,6\%, Szwecja 11\% czy Szwajcaria 12,6\%). Natomiast sprzedaż w Polsce produktów ekologicznych w 2015 roku wyniosła $167 \mathrm{mln}$ euro ( $0,6 \%$ wartości rynku europejskiego) i jest to wyraźny wzrost w ostatnich latach bo w 2008 roku wyniósł on $50 \mathrm{mln}$ euro. Jednak wydatki jednostkowe na produkty ekologiczne w Polsce wyniosły w 2015 roku jedynie 4 euro (przy średniej europejskiej 60 euro) choć były 3-krotnie wyższe niż w 2008 roku (Willer, Lernoud, 2018; Weidmann i in., 2010).

Rola rolnictwa ekologicznego w Polsce w okresie ostatnich kilkunastu lat wzrosła, o czym świadczy zwiększenie udziału ekologicznych użytków rolnych w ogóle użytków rolnych 7krotnie do prawie $4 \%$ oraz udziału gospodarstw ekologicznych 12-krotnie do 1,6\% wszystkich gospodarstw w kraju. W okresie 2004-2016 liczba wszystkich ekologicznych producentów prowadzących produkcję rolniczą (gospodarstw rolnych) w Polsce zwiększyła się 6-krotnie do 22,4 tys. Prawie $79 \%$ z nich stanowiły gospodarstwa już po konwersji. Liczba tych gospodarstw wzrosła w latach 2004-2016 ponad 10 razy, a gospodarstw w trakcie konwersji o 130\%. W tych samych latach powierzchnia ekologicznych użytków rolnych zwiększyła się 6,5- krotnie do prawie 537 tys. ha, z czego $80 \%$ było już po konwersji. W ostatnich kilku latach zauważalny jest jednak spadek zarówno liczby ekologicznych producentów rolnych, jak i powierzchni ekologicznych użytków rolnych (IJHAR-S, 2018). Jedną z przyczyn tego zjawiska mogą być wprowadzone nowe przepisy prawne (Rozporządzenie, 2015), w których uzależniono przyznanie płatności ekologicznej w ramach niektórych pakietów od posiadania przez rolnika odpowiedniej ilości zwierząt. Spowodowało to urealnienie ekologicznej produkcji rolnej w kraju, eliminując z rynku m.in. tzw. „łakarzy”, którzy poza pobieraniem dopłat do produkcji ekologicznej niewiele mieli z nią wspólnego. Potwierdziło to, że jednym z głównych czynników stymulującym rozwój rolnictwa ekologicznego w Polsce, szczególnie od 2004 roku, były i są dopłaty do produkcji ekologicznej w ramach WPR (Brodzińska, 2010; Kisiel, Grabowska, 2014). Wciąż utrzymuje się wysoka koncentracja ekologicznych gospodarstw rolnych i powierzchni ekologicznych użytków rolnych w kilku regionach kraju (Zuba-Ciszewska, Zuba, 2016).

Intensywny rozwój światowego rynku żywności ekologicznej, w tym rosnące zapotrzebowanie na produkty mleczarskie, stwarzają szansę polskim mleczarniom na poprawę swych wyników poprzez włączenie się $\mathrm{w}$ ich sprzedaż. Jednak produkcja mleka ekologicznego w Polsce w 2016 roku wyniosła 24,2 mln litrów czyli mniej o 1,9 mln 1 niż w 2004 roku. W ostatnich kilku latach zaobserwować można wyraźną tendencję spadkową w wielkości produkcji ekologicznego mleka w kraju. Jednocześnie jest to dość gwałtowny spadek, bo aż o 39\% w porównaniu do 2011 roku. Jest to sytuacja odwrotna niż w przypadku produkcji mleka krowiego ogółem w kraju, dla której trend jest wzrostowy. Obecnie produkcja mleka ekologicznego stanowi niewiele, bo $0,19 \%$ wielkości produkcji 


\section{J. Bednarz, M. Zuba-Ciszewska}

mleka ogółem (a jeszcze w 2011 r. było to 0,33\%) [IJHAR-S 2018]. Inaczej sytuacja wygląda w UE. Produkcja ekologicznego mleka krowiego w UE systematycznie rośnie (w latach 2007-2016 z 2,4 do 4,1 mln ton) i stanowi obecnie 2,5\% produkcji mleka ogółem (Willer, Lernoud, 2018; Weidmann i in., 2010). Dlatego o ile w produkcji mleka krowiego ogółem Polska zajmuje czwarte miejsce w UE z udziałem powyżej $8 \%$, to w produkcji mleka ekologicznego jest to jedynie $0,56 \%$, a więc znacznie poniżej swoich możliwości produkcyjnych. Produkcję ekologiczną mleka krowiego w Polsce cechuje silna koncentracja w regionach, która w ostatnich latach się nasiliła.

Wyjaśnienia zjawiska specjalizacji regionalnej można upatrywać w dwóch nurtach klasycznej myśli ekonomicznej. Pierwszy z nich wynika bezpośrednio z teorii przewagi komparatywnej (Ricardo, 1821), przy potraktowaniu jednostki terytorialnej - regionu jako całości. Zgodnie z tym nurtem produkcja specyficznego dobra opiera się na przewadze komparatywnej wynikającej bezpośrednio z produktywności pracy między regionami. Według tego toku analizy w danym regionie wytwarzane są dobra i usługi, jeżeli względna ich cena jest wyższa niż koszt alternatywny. Na gruncie teorii przewagi komparatywnej North zauważył, że dodatni bilans towarowy $\mathrm{w}$ wymianie regionalnej wynikający $\mathrm{z}$ przewagi konkurencyjnej dodatnio wpływa na stabilizację ekonomiczną regionu i perspektywy jego rozwoju. Produkcja wysokojakościowych dóbr może stanowić motor rozwoju w skali regionalnej. Ten zewnętrzny proces sprzedaży ma wpływ na przewage komparatywną wynikającą z rozwoju produktu, ponieważ nieustanne „otwiera” rynki regionów sąsiadujących, co jednoznacznie stymuluje producentów do utrzymywania wysokich standardów jakościowych (North, 1955).

Innym podejściem, które broni specjalizacji produktowej jako siły napędowej rozwoju ekonomicznego jest teoria Kaldora, w myśl której dynamika ekonomiczna jest bezpośrednio związana ze specjalizacją produktową. Ze względu na rosnące przychody ze sprzedaży produktów specjalistycznych, regiony specjalizujące się w danej działalności w porównaniu z innymi regionami mogą rozwijać się szybciej (Kaldor, 1970). Jednym z argumentów jest to, że wzrost wydajności zależy głównie od stopnia zmiany postępu technicznego, a przede wszystkim opłacalności produkcji. Pożądany proces kumulatywny wynikający zopłacalności produkcji ma fundamentalne znaczenie dla utrzymania ekonomicznych ram działalności rolniczej. Utrzymanie opłacalności produkcji decyduje o konkurencyjności produktów na rynkach regionów sąsiednich (Dixon, Thirwall, 1975).

W nowszych badaniach Krugman przedstawił wyjaśnienie specjalizacji produkcji, nie tylko dotyczące globalnego podziału gospodarek, ale także specjalizacji produkcji w ujęciu regionalnym (Krugman, 1992). Krytykuje on uproszczone myślenie wynikające z tradycyjnej ekonomii, która kładzie niewielki nacisk na lokalizację czynników produkcji. Podkreśla, że jednym z najlepszych sposobów zrozumienia funkcjonowania gospodarek w ujęciu regionalnym i międzynarodowym jest analiza cech charakterystycznych każdego regionu. W ten sposób ukształtowała się nowa linia badawcza o nazwie „Nowa geografia ekonomiczna". Przedmiotem jej zainteresowania jest identyfikacja klastrów gospodarczych w przestrzeni geograficznej (Fujita, Krugman, 2004), ponieważ koncentracja geograficzna ma tendencję do wpływania na wydajność i opłacalność produkcji. Klastry są postrzegane jako uprzywilejowane przestrzenie $\mathrm{z}$ większą zdolnością do generowania bogactwa. Ważnym zagadnieniem w przypadku funkcjonowania produkcji mleka ekologicznego pozostaje kwestia właściwego systemu transportu, który bezpośrednio przyczynia się do otwierania i utrzymania sieci powiązań na lokalnych rynkach. Oznacza to, że mamy do czynienia z procesami akumulacji, które generują korzyści ekonomiczne dla regionu. 
Krugman w swoim przemówieniu odbierając Nagrodę Nobla (2008) zwrócił uwagę, że jeśli korzyści skali regionu przewyższają koszty logistyki transportu, a także jeśli część populacji osób $\mathrm{w}$ wieku produkcyjnym zrezygnuje $\mathrm{z}$ poszukiwania zatrudnienia poza swoim regionem, wtedy rosną szanse na tworzenie specjalistycznych klastrów wiedzy regionalnej i przestrzenną koncentrację działalności produkcyjnej w danym regionie.

\section{Cel i metoda badań}

Celem pracy było zbadanie stopnia koncentracji rynku mleka ekologicznego na tle rynku mleka ogółem, a także próba odpowiedzi na pytanie o możliwość wskazania regionów specjalizujących się $\mathrm{w}$ produkcji mleka ekologicznego. Problem badawczy polegał na rozstrzygnięciu, czy w przypadku produkcji mleka ekologicznego mamy do czynienia z koncentracja produkcji, czy raczej - ze względu na niski udział produkcji mleka ekologicznego względem mleka ogółem - raczej z jej rozproszeniem.

Pomiar koncentracji stanowi jedno $\mathrm{z}$ kluczowych zagadnień $\mathrm{w}$ badaniach nad ekonomicznymi strukturami zjawisk rynkowych. W rozumieniu ekonomicznym zjawisko koncentracji może dotyczyć udziałów w rynkach docelowych. Chodzi najczęściej o zbadanie siły rynkowej dostawcy produktów i usług [Grzybowski 2008]. Przedmiotem szczególnego zainteresowania staje się wtedy jego ewentualna dominująca lub wręcz bliska monopolistycznej pozycja rynkowa (Krstić, Radivijević, Stanišić, 2016). Koncentracje aktywności ekonomicznej w odniesieniu do produkcji, usług, ale także zatrudnienia, można postrzegać jako rodzaj specjalizacji. W tym przypadku koncentracja oznaczać będzie zgrupowanie wyspecjalizowanych przedsiębiorstw oraz osób związanych z branżą, w której ci producenci prowadzą działalnością gospodarczą (Prager, Thisse, 2012). Taki rodzaj koncentracji jest postrzegany jako pozytywnie oddziałujący na bezpośrednie otoczenie ekonomiczne, ponieważ specjalizacja jednych poprzez tzw. spill-over effect stwarza szansę na powstanie nowych miejsc pracy (Mora, Moreno, 2010).

Klasyczne ujęcie zagadnienia koncentracji, zarówno w badaniach udziałów w rynkach, jak też nad specjalizacją $\mathrm{w}$ produkcji i usługach - ze szczególnym uwzględnieniem perspektywy terytorialnej/regionalnej - nakazuje odpowiedni dobór metody badawczej. Z literatury przedmiotu wynika, że podstawową miarą służącą badaniu koncentracji rynku jest indeks Herfindahla-Hirschmana (HHI) (Kwiatkowska, 2014; Hoxka, 2013; Bashorun, Ojapinwa, 2014). Indeks ten (HHI) jest sumą kwadratów udziałów $\left(\mathrm{x}_{\mathrm{i}}\right)$ w rynku mleka, poszczególnych aktorów.

$\mathrm{Na}$ potrzeby niniejszego opracowania wykorzystano zmodyfikowaną (Bednarz, Kozłowski, 2017) postać metody unitaryzacji zerowanej jako formuły umożliwiającej porządkowanie liniowe. Zastosowanie metody unitaryzacji zerowanej umożliwia stworzenie rankingu obiektów (tu: województw) na podstawie wyników zawierających się w przedziale zamkniętym $[0,1]$. Analiza tak uporządkowanych wyników pozwala na jednoznaczną interpretację odczytów. Im bliżej wartości 1, tym większym stopniem obserwowanej cechy lub zespołu cech charakteryzuje się badany obiekt. Wartości dążące do zera wskazują że badana cecha (względnie zespół cech) występują w stopniu nikłym, albo też nie są obserwowane. Należy zastrzec, że opracowana przez Kukułę (2000) metoda unitaryzacji zerowanej jest tylko jedną $\mathrm{z}$ wielu metod taksonomicznych umożliwiających porządkowanie liniowe. Na uwagę zasługuje powszechność i uniwersalność jej stosowania (Kukuła, Bogacz, 2014; Jarocka, 2015; Bluszcz, 2016; Walesiak, 2017). Dla każdego z 


\section{J. Bednarz, M. Zuba-Ciszewska}

badanych obiektów (województw) można obliczyć wartość wskaźnika intensywności obserwowanej cechy rozumianej jako produkcja mleka ekologicznego jako udziału procentowego w łącznej produkcji mleka w danym województwie. Wskaźnik ten wyraża się wzorem:

$$
I_{i t}=\frac{v_{i t}-v_{\min t}}{v_{\max t}-v_{\min t}},
$$

gdzie: $\left(v_{i t}\right)$ oznacza procentowy udział produkcji mleka ekologicznego w produkcji mleka ogółem w i-tym województwie w czasie $(t)$. W liczniku przedstawionego równania od wartości $\left(v_{i t}\right)$ odejmujemy wartość najniższą $\left(v_{\min } t\right)$ w danym okresie. Mianownik rozumiany jako różnica między najwyższą i najniższą wartością odczytów w badanym okresie stanowi wielkość, dzięki której możliwa jest normalizacja uzyskiwanych wyników $\mathrm{i}$ ich uporządkowanie w zbiorze zamkniętym $[0,1]$.

Zastosowanie tak konstruowanego wskaźnika prowadzi do uzyskania wyników dla wszystkich badanych województw $\mathrm{w}$ przedziale $[0,1]$. Oznacza to, że dla każdego badanego okresu wskazane zostanie obiekt (województwo), z najsilniej i najsłabiej obserwowaną cechą (mleko ekologiczne produkowane na jego terenie). Obiektowi o najsilniejszym odczycie przypisana zostanie wartość 1 , zaś obiektowi z najsłabszym odczytem przypisana będzie wartość zerowa. Niejaka trudność stosowanej miary wynika z faktu, że kłopotliwe jest międzyokresowe porównanie tak otrzymanych odczytów (Bednarz, Kozłowski, 2017). Możliwym w tym przypadku zabiegiem jest rezygnacja ze wskazywania odczytu maksymalnej i minimalnej wartości wskaźnika $\left(v_{i t}\right)$ w każdym okresie badania $(t)$. Ferreri $(2006,2010)$ zaproponował, aby używać tylko jednego wskaźnika o wartości maksymalnej $\left(v_{\max }\right)$ i jednego dla wartości minimalnej $\left(v_{\min }\right)$ dla wszystkich okresów prowadzonego badania. Dodatkowo wprowadził też aspekt analityczny w postaci wielkości i objętości cechy względem miary odniesienia. Na użytek zaproponowanej formuły Ferreri jako wielkość rozumie procentowy udział wartości odczytu cechy pojedynczego obiektu względem sumy wartości tej cechy zmierzonej łącznie dla wszystkich obiektów. Jako objętość należy rozumieć wartość zmiennej, względem której odnoszona jest cecha, zmierzonej dla badanego obiektu wobec sumy tej wartości dla wszystkich obiektów łącznie. W naszym przypadku parametr wielkości $(\alpha)$ należy rozumieć jako wielkość produkcji mleka ekologicznego realizowanej na terenie $i$-tego województwa w czasie $(t)$ wobec łącznej wartości produkcji mleka ekologicznego we wszystkich województwach w tym czasie. Jako parametr objętości $(\beta)$ będziemy rozumieć wielkość produkcji mleka ogółem na terenie pojedynczego województwa w czasie $(t)$ wobec sumy produkcji mleka ogółem dla wszystkich województw w tym czasie. Zgodnie ze wskazówkami Ferrieriego (2006) tak rozumiany wskaźnik będzie miał postać:

$$
I_{i t}=\left(\frac{v_{i t}-v_{\min }}{v_{\max }}\right)^{(1-\alpha)(1-\beta)}
$$

Parametry $(\alpha)$ oraz $(\beta)$ widoczne są w wykładniku potęgi będącego iloczynem uwzględniającym aspekt wartości badanej cechy względem wartości opisującej wielkość odniesienia. 
Jak zauważają Bednarz i Kozłowski (2017) proponowana przez Ferrieriego (2006) formuła badania intensywności cechy może zostać łatwo przekształcona do postaci wykorzystującej uznaną za uniwersalną (Jarocka, 2015) w swoim zastosowaniu metodę unitaryzacji zerowanej. Wartość wskaźnika intensywności cechy będzie można obliczyć na podstawie wzoru:

$$
I_{i t}=\left(\frac{v_{i t}-v_{\min }}{v_{\max }-v_{\min }}\right)^{(1-\alpha)(1-\beta)}
$$

W pracy wykorzystano dane opublikowane przez Główny Urząd Statystyczny, raporty o stanie rolnictwa ekologicznego w Polsce przygotowane przez IJHAR-S (Inspekcja Jakości Produktów Rolno-Spożywczych), oraz raporty o stanie rolnictwa ekologicznego na świecie opracowane przez FiBL i IFOAM (Instytut Badawczy Rolnictwa Ekologicznego i Międzynarodową Federację Organizacji Rolnictwa Ekologicznego). Dane obejmowały okres 2009-2016. Dodatkowo, aby uwzględnić stan rzeczy w okresie przystępowania Polski do UE, wykorzystano dane za rok 2004.

\section{Wyniki badań}

Od wielu lat w kraju regionami o największym produkcji mleka krowiego (tab. 1) są: mazowieckie, podlaskie i wielkopolskie (w 2016 roku z udziałem 54,7\% w 12867,2 $\mathrm{mln} 1$ produkcji krajowej). Natomiast $\mathrm{w}$ produkcji ekologicznej tego surowca obecnie wyraźnie dominują trzy regiony tj.: małopolskie, podkarpackie i zachodniopomorskie, $\mathrm{z}$ udziałem $56,5 \%$ z 24,2 mln 1 mleka czyli dwukrotnie więcej niż w 2004 roku $(28,2 \%)$. Są to regiony o niewielkiej produkcji mleka ogółem $(5,6 \% \mathrm{w}$ kraju) oraz nie cechują się one (poza podkarpackim) najwyższą przydatnością do produkcji ekologicznej, obejmującą różne kryteria środowiskowe (Krasowicz, 2009).

Indeks HHI określający stopień koncentracji produkcji na rynku mleka ogółem oraz mleka ekologicznego, obliczony jako suma kwadratów udziałów poszczególnych województw w jego produkcji, wskazuje na wyższy stopień koncentracji produkcji mleka ekologicznego niż mleka ogółem (rys. 1).

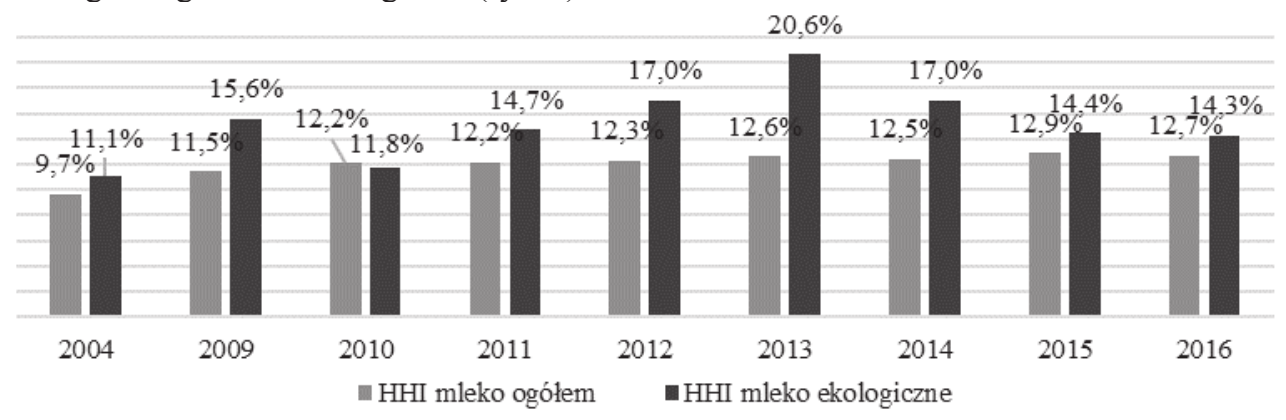

Rys. 1. Stopień koncentracji produkcji mleka krowiego, w tym ekologicznego w Polsce

Fig. 1. The degree of concentration of cow's milk production, including organic milk in Poland

Źródło: Opracowanie własne na podstawie danych GUS i IJHAR-S. 


\section{J. Bednarz, M. Zuba-Ciszewska}

Rynek mleka ogółem w roku przystąpienia Polski do UE można było zakwalifikować jako rozproszony (nieskoncentrowany), ze względu na wartość HHI poniżej 10\% (Krstić $\mathrm{i}$ in., 2016). Wraz z upływem czasu zwiększał się stopień koncentracji, jednak nadal można było uważać, że rynek mleka ogółem w Polsce jest co najwyżej umiarkowanie skoncentrowany. Indeks HHI nie może być wykorzystany do wskazania (podmiotów) regionów odpowiedzialnych za wyższy niż w przypadku mleka ogółem stopień koncentracji rynku mleka ekologicznego. Nie pozwalają na to również inne podobnie zbudowane wskaźniki (Marfels, 1971; Kaivo-oja i in., 2017). Przy ich pomocy można zbadać stopień koncentracji rynku, ale nie udaje się podmiotowo wykazać stopnia odpowiedzialności za taki stan rzeczy.

Tab. 1. Struktura produkcji mleka krowiego w Polsce (Polska=100\%)

Tab. 1. The structure of the cow's milk production in Poland (Poland $=100 \%$ )

\begin{tabular}{|c|c|c|c|c|c|c|c|c|c|c|}
\hline Województwa & Mleko & 2004 & 2009 & 2010 & 2011 & 2012 & 2013 & 2014 & 2015 & 2016 \\
\hline \multirow{2}{*}{ dolnośląskie } & ekologiczne & 1,42 & 3,21 & 3,70 & 3,01 & 2,88 & 3,69 & 4,43 & 3,90 & 3,42 \\
\hline & ogółem & 2,02 & 1,62 & 1,44 & 1,51 & 1,56 & 1,53 & 1,60 & 1,48 & 1,38 \\
\hline \multirow{2}{*}{ kujawsko-pomorskie } & ekologiczne & 1,49 & 2,81 & 3,36 & 1,60 & 2,36 & 3,37 & 2,66 & 5,11 & 3,98 \\
\hline & ogółem & 5,88 & 7,34 & 7,29 & 7,21 & 6,86 & 7,06 & 7,14 & 7,22 & 7,37 \\
\hline \multirow{2}{*}{ lubelskie } & ekologiczne & 8,33 & 2,98 & 2,98 & 2,19 & 1,01 & 0,97 & 0,59 & 0,64 & 0,78 \\
\hline & ogółem & 8,12 & 6,81 & 6,23 & 5,99 & 6,07 & 5,69 & 5,91 & 6,09 & 5,90 \\
\hline \multirow{2}{*}{ lubuskie } & ekologiczne & 1,13 & 0,28 & 0,33 & 0,06 & 0,00 & 0,68 & 0,85 & 0,37 & 0,16 \\
\hline & ogółem & 1,14 & 0,98 & 0,91 & 0,99 & 0,95 & 0,87 & 0,84 & 0,66 & 0,65 \\
\hline \multirow{2}{*}{ łódzkie } & ekologiczne & 1,67 & 1,19 & 0,65 & 1,53 & 0,90 & 0,99 & 1,19 & 0,99 & 0,94 \\
\hline & ogółem & 8,82 & 8,34 & 8,08 & 7,94 & 7,67 & 7,68 & 8,31 & 7,63 & 7,69 \\
\hline \multirow{2}{*}{ małopolskie } & ekologiczne & 11,14 & 30,27 & 21,57 & 29,18 & 32,98 & 38,60 & 31,87 & 27,67 & 26,43 \\
\hline & ogółem & 5,36 & 3,20 & 2,96 & 2,88 & 3,11 & 2,85 & 2,84 & 2,52 & 2,80 \\
\hline \multirow{2}{*}{ mazowieckie } & ekologiczne & 18,15 & 9,01 & 8,78 & 7,94 & 4,65 & 5,00 & 3,26 & 9,17 & 9,39 \\
\hline & ogółem & 17,81 & 20,30 & 23,26 & 21,99 & 21,64 & 21,53 & 21,72 & 21,73 & 20,93 \\
\hline \multirow{2}{*}{ opolskie } & ekologiczne & 0,26 & 0,06 & 0,20 & 0,07 & 0,01 & 0,03 & 0,00 & 0,00 & 0,00 \\
\hline & ogółem & 2,47 & 2,13 & 2,43 & 2,13 & 2,14 & 2,00 & 2,18 & 2,07 & 2,12 \\
\hline \multirow{2}{*}{ podkarpackie } & ekologiczne & 11,31 & 15,21 & 13,53 & 15,16 & 14,56 & 17,65 & 14,40 & 15,07 & 15,99 \\
\hline & ogółem & 4,01 & 2,78 & 2,28 & 2,11 & 1,93 & 1,99 & 1,82 & 1,79 & 1,68 \\
\hline \multirow{2}{*}{ podlaskie } & ekologiczne & 6,90 & 5,90 & 6,19 & 4,42 & 4,06 & 3,51 & 2,77 & 4,44 & 5,08 \\
\hline & ogółem & 14,10 & 17,63 & 16,52 & 18,23 & 18,47 & 19,12 & 18,77 & 19,94 & 20,08 \\
\hline \multirow{2}{*}{ pomorskie } & ekologiczne & 4,62 & 1,65 & 6,46 & 5,53 & 5,81 & 1,81 & 7,48 & 6,54 & 6,87 \\
\hline & ogółem & 3,05 & 2,52 & 2,40 & 2,55 & 2,68 & 2,90 & 2,84 & 2,72 & 2,75 \\
\hline \multirow{2}{*}{ śląskie } & ekologiczne & 0,16 & 0,68 & 0,69 & 0,34 & 0,26 & 0,35 & 0,43 & 0,39 & 0,29 \\
\hline & ogółem & 2,68 & 2,09 & 1,92 & 1,76 & 1,96 & 1,95 & 1,90 & 1,87 & 2,01 \\
\hline \multirow{2}{*}{ świętokrzyskie } & ekologiczne & 14,14 & 5,75 & 7,05 & 7,14 & 5,69 & 6,98 & 3,97 & 4,09 & 4,56 \\
\hline & ogółem & 3,77 & 2,96 & 3,07 & 3,19 & 2,55 & 2,16 & 1,95 & 1,99 & 1,94 \\
\hline \multirow{2}{*}{ warmińsko-mazurskie } & ekologiczne & 12,36 & 13,13 & 10,54 & 11,23 & 12,07 & 11,05 & 8,83 & 7,60 & 7,91 \\
\hline & ogółem & 7,44 & 7,51 & 7,74 & 7,81 & 7,71 & 7,18 & 7,75 & 7,46 & 7,90 \\
\hline \multirow{2}{*}{ wielkopolskie } & ekologiczne & 1,23 & 0,39 & 0,60 & 1,54 & 1,03 & 0,63 & 0,43 & 0,31 & 0,11 \\
\hline & ogółem & 11,43 & 12,24 & 12,00 & 12,23 & 13,22 & 14,20 & 13,04 & 13,46 & 13,64 \\
\hline \multirow{2}{*}{ zachodniopomorskie } & ekologiczne & 5,71 & 7,48 & 13,38 & 9,06 & 11,75 & 4,71 & 16,84 & 13,71 & 14,09 \\
\hline & ogółem & 1,92 & 1,54 & 1,46 & 1,49 & 1,49 & 1,28 & 1,38 & 1,34 & 1,14 \\
\hline
\end{tabular}

Źródło: opracowanie własne na podstawie danych GUS i IJHAR-S. 
Interpretacja udziałów procentowych w rynku na podstawie danych statystycznych, które nie zostały przetworzone przy pomocy narzędzi statystycznych, jest obarczone błędem (Binderman i in., 2015). Aby uzyskać jednoznaczną interpretację odczytów intensywności cechy wykorzystano metodę unitaryzacji zerowanej jako formuły umożliwiającej porządkowanie liniowe. Pozwala ona na jednoznaczną identyfikację regionów, w których produkcja mleka ekologicznego ma większe znaczenie ekonomiczne.

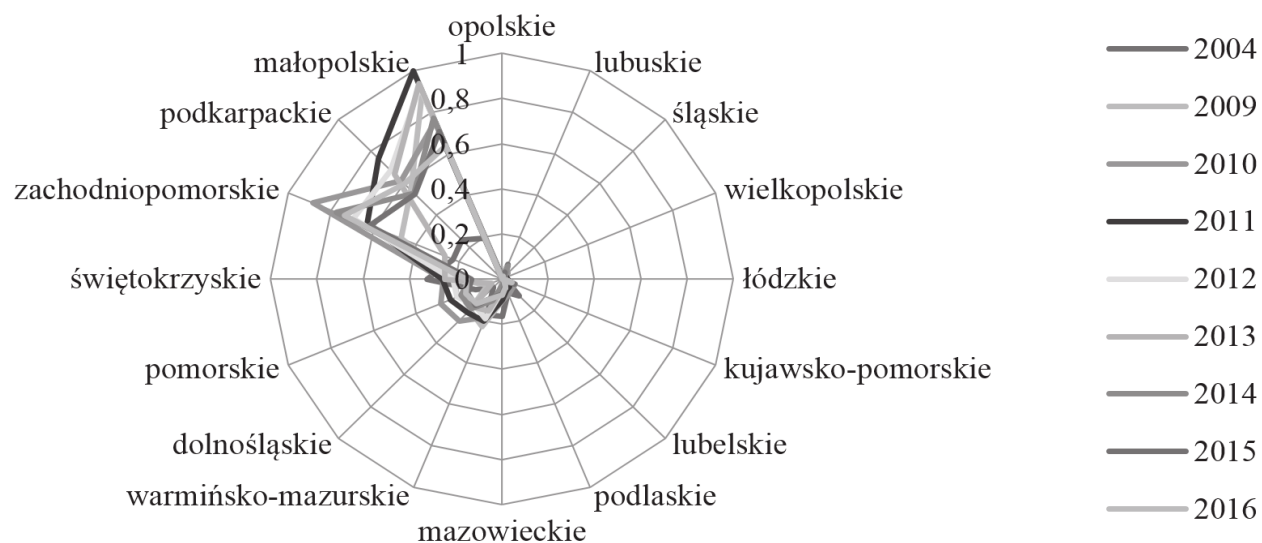

Rys. 2. Intensywność produkcji mleka ekologicznego w Polsce

Fig. 2. Intensity of the organic milk production in Poland

Źródło: opracowanie własne na podstawie danych GUS i IJHAR-S.

Przeprowadzona analiza koncentracji rynku mleka ekologicznego w ujęciu regionalnym wskazuje jednoznacznie, że stopień jego koncentracji - w każdym z badanych okresów jest wyższy niż ma to miejsce w przypadku rynku mleka ogółem. Nie ma więc podstaw, aby twierdzić, że rynek dostaw mleka ekologicznego ma charakter rozproszony. Pomimo nieznacznego udziału produkcji mleka ekologicznego w porównaniu z produkcją mleka ogółem można jednoznacznie wskazać regiony, dla których produkcja mleka ekologicznego ma zauważalnie większe znaczenie. Otrzymane wyniki ilustruje wykres 2. Podstawą takiego stwierdzenia jest badanie wykorzystujące zmodyfikowaną formułę metody unitaryzacji zerowanej. W analizowanym okresie regionami znacząco wyróżniającymi się w produkcji mleka ekologicznego w skali kraju były województwa małopolskie, podkarpackie oraz zachodniopomorskie. Odczyty znormalizowanego pomiaru w przedziale zamkniętym [0,1] sytuują wskazane województwa w dwóch górnych z pięciu przedziałów skali pomiarowej. Szczególnie interesujące są odczyty dla województwa zachodniopomorskiego, które wskazują na rozwój i wzrost ilościowy produkcji mleka ekologicznego. Obserwacja ta jest interesująca z naukowego punktu widzenia ze względu na odmienne uwarunkowania rozwoju produkcji mleka w porównaniu z województwami podkarpackim i małopolskim (Parzonko, 2013). Odczyty wyników dla pozostałych województw mieszczą się w badanym okresie w dwóch dolnych z pięciu przedziałów skali pomiarowej. Otrzymane wyniki mogą być postrzegane jako potwierdzenie znaczącego zróżnicowania rozkładu. Rozdrobnienie producentów, co poniekąd jest zrozumiale wobec 
niszowego charakteru produktu, jakim jest mleko ekologiczne, nie jest więc tożsame z rozproszeniem rynkowym.

\section{Podsumowanie i wnioski}

Przeciętna produkcja ekologicznego mleka krowiego w gospodarstwie jest w skali kraju niewielka (średnio 28,2 tys. 1). Jedynie w kilku regionach, i to tylko w dwóch specjalizujących się w produkcji mleka ekologicznego, średnia produkcja w gospodarstwie jest wyższa od krajowej (dolnośląskie 31,8 tys. 1, kujawsko-pomorskie 59,4 tys. 1, pomorskie 151,1 tys. 1, warmińsko-mazurskie 79,8 tys. 1, zachodniopomorskie 162,4 tys. 1) (IJHAR-S, 2018). Pomimo wykazanej w badaniach zauważalnej koncentracji struktury rynku produkcji mleka ekologicznego, jednym z czynników ograniczających przetwórstwo ekologiczne jest silne rozdrobnienie produkcji tego surowca. Zarazem jednak obserwacja koncentracji rynku wskazuje na możliwość kształtowania się swoistej specjalizacji regionalnej. Przetwórstwem ekologicznego mleka zajmuje się coraz więcej mleczarni (21 w 2016 roku). Ponad 99\% wytworzonych ekologicznych produktów mleczarskich pochodzi z województwa mazowieckiego, pomorskiego, kujawsko-pomorskiego i podlaskiego (IJHAR-S, 2018). Dlatego postępującą specjalizację regionalną w produkcji mleka ekologicznego należy odnotować z uwagą, mimo iż nie pokrywa się ona ze specjalizacją w przetwórstwie tego surowca. Wykorzystanie potencjału rynku ekologicznych produktów mleczarskich przez krajowe mleczarnie uzależnione jest od zwiększenia przez gospodarstwa rolne produkcji ekologicznego mleka. Konieczne jest zintensyfikowanie relacji między mleczarnią a rolnikami-dostawcami, szczególnie w regionach wykazujących specjalizację $\mathrm{w}$ produkcji mleka.

\section{Literatura}

Bashorun, T., Ojapinwa, V. (2014). Bank Consolidation and Market Structure in Nigeria: Application of the Herfindahl-Hirschman Index, International Journal of Economics and Finance, 6 (2), 235-243.

Bednarz, J., Kozłowski, E. (2017). Czy należy poprawiać (usprawniać) metodę unitaryzacji zerowanej (Does the zero unitarization method need to be improved (enhanced)?). Referat wygłoszony w ramach XIX Konferencji Naukowej, Rogów, June $20^{\text {th }}, 2017$.

Binderman, Z., Borkowski, B., Szczęsny, W. (2015). Application of Minkowski's metric in measuring changes of concentration of value added in agriculture, forestry, fishing and hunting sectors. Acta Scientiarum Polonorum. Oeconomia, 14 (2), 17-28.

Bluszcz, A. (2016). Classification of the European Union member states according to the relative level of sustainable development. Quality \& Quantity, 50 (6), 2591-2605.

Brodzińska, K. (2010). Rozwój rolnictwa ekologicznego w Polsce na tle uwarunkowań przyrodniczych i systemu wsparcia finansowego (Organic farming development in Poland in context of environmental conditions and financial support system), Problemy Rolnictwa Światowego, 10(2), 12-21.

Dixon, R., Thirwall, A. (1975). A model of regional growth-rate differences on kaldorian lines. Oxford economic papers, 27 (2), 201-214.

Ferrieri, G. (2006). A Method for Measuring International Openness. Social Indicators Research, 77 (2), 245-255.

Ferrieri, G. (2010). Measuring Openess. Journal of Modern Applied Statistical Methods, 9 (1), 172-180.

Fujita, M., Krugman, P. (2004). The new economic geography: past, present and the future. Papers in Regional Science, 83, 139-164.

Grzybowski, L. (2008). The competitiveness of mobile telephony across the European Union. International Journal of the Economics of Business, 15, 99-115. 
Hoxha, I. (2013). The market structure of the banking sector and financially dependent manufacturing sectors. International Review of Economics and Finance, 27, 432-444.

IJHAR-S (2018). Pobrano 26.10.2018 z: http://www.ijhar-s.gov.pl/index.php/raporty-o-ekologii.html.

Jarocka, M. (2015). Wybór formuły normalizacyjnej w analizie porównawczej obiektów wielocechowych. (The choice of a formula of the data normalization in the comparative analysis of multivariate objects). Ekonomia $i$ Zarzadzanie, 1, 113-126.

Kaivo-oja, J., Vähäsantanen, S., Karppinen, A., Haukioja, T. (2017). Smart specialization strategy and its operationalization in the regional policy: case Finland. Business, Management and Education, 15(1), 28-41.

Kaldor, N. (1970). The case for regional policies, Scottish Journal of Political Economy, 17 (3), 337-348.

Kisiel, R., Grabowska, N. (2014). Rola dopłat unijnych w rozwoju rolnictwa ekologicznego w Polsce na przykładzie województwa podlaskiego (The role of European Union subsidies in the development of organic farming in Poland - an example of Podlasie region). Woda-Środowisko-Obszary Wiejskie, 14 (47), 61-73.

Krasowicz, S. (2009). W Polsce powinno dominować rolnictwo zrównoważone (In Poland, sustainable agriculture should dominate). [W] Przyszłość sektora rolno-spożywczego i obszarów wiejskich (The future of the agrifood sector and rural areas), A. Harasim (red.), IUNG-PIB, Puławy, 21-38.

Krstić, B., Radivijević, V., Stanišić, T. (2016). Measuring and Analysis of competition intensity in the Sugar Market in Serbia. Economics of Agriculture, 63 (2), 389-406.

Krugman, P. (1992). A dynamic spatial model. NBER Working Paper, no. 4219.

Krugman, P. (2008). The Increasing returns revolution in trade and geography. Pobrano 26.10.2018 z: https:/www.nobelprize.org/uploads/2018/06/krugman_lecture.pdf []

Kukuła, K., Bogacz, D. (2014). Zero Unitarisation Method and its application in Ranking Research in Agriculture. Economic and Regional Studies, 7 (3), 5-13.

Kukuła, K. (2000). Metoda unitaryzacji zerowanej (Zero Unitarization Method). Wydawnictwo Naukowe PWN, Warszawa.

Kwiatkowska, E. (2014). Miary koncentracji - teoria a praktyka wykorzystania przez organy regulacyjne na rynkach telekomunikacyjnych (Measure of Market Conccentration - Theory and Practice of their Use by Regulatory Authorities in the Telecommunication Markets). Metody Ilościowe $w$ Badaniach Ekonomicznych, 15(3), 189-198.

Marfels, C. (1971). Absolute and relative measures of concentration reconsidered, Kyklos, 24 (4), 753-766.

Mora, T., Moreno, R. (2010). Specialization changes in European regions: the role played by externalities across regions. Journal of Geographical Systems, 12, 311-334.

North, D. (1955). Location theory and regional economic growth. Journal of Political Economy, 63 (3), 243-258.

Parzonko, A. (2013). Globalne i lokalne uwarunkowania rozwoju produkcji mleka (Global and local conditions for the development of milk production). Wydawnictwo SGGW, Warszawa.

Prager, J-C., Thisse, J-F. (2012). Economic geography and the unequal development of regions, Routledge, London and New York.

Ricardo, D. (1821). Principles of political economy and taxation. John Murray, London.

Rozporządzenie Ministra Rolnictwa i Rozwoju Wsi z dnia 13 marca 2015 r. W sprawie szczegółowych warunków i procedur przyznawania pomocy finansowej w ramach działania "Rolnictwo ekologiczne" zawartego w Programie Rozwoju Obszarów Wiejskich na lata 2014-2020.

Walesiak, M. (2017). Wizualizacja wyników porządkowania liniowego dla danych porządkowych z wykorzystaniem skalowania wielowymiarowego (Visualization of linear ordering results for oridinal data with application of multidimensional scaling), Przeglad Statystyczny, 61 (1), 5-19.

Weidmann, G., Kilcher, L., Garibay, S. (2010). The world of organic agriculture. Statistics and emerging trends 2010, FiBL \& IFOAM, Frick and Bonn.

Willer, H., Lernoud, J. (2018). The world of organic agriculture. Statistics and emerging trends 2018, FiBL \& IFOAM, Frick and Bonn.

Zuba-Ciszewska, M., Zuba, J. (2016). Miejsce ekologicznej produkcji rolniczej w polskim rolnictwie (The place of the organic farm output in the Polish agriculture), Roczniki Naukowe SERiA, 18(3), 411-418.

Do cytowania / For citation:

Bednarz J., Zuba-Ciszewska M. (2018). Produkcja mleka ekologicznego w Polsce. Koncentracja czy rozproszenie? Problemy Rolnictwa Światowego, 18(4), 112-121; DOI: 10.22630/PRS.2018.18.4.102

Bednarz J., Zuba-Ciszewska M. (2018). Organic Milk Production in Poland. Concentration or Dispersion? (in Polish). Problems of World Agriculture, 18(4), 112-121;

DOI: $10.22630 /$ PRS.2018.18.4.102 